Man and Nature

L'homme et la nature

\title{
'Those Damn Sacred Hymns': Some Problems with the Ontology of 'Text'
}

\section{Richard Arnold}

Volume 9, 1990

URI : https://id.erudit.org/iderudit/1012610ar

DOI : https://doi.org/10.7202/1012610ar

Aller au sommaire du numéro

Éditeur(s)

Canadian Society for Eighteenth-Century Studies / Société canadienne d'étude du dix-huitième siècle

ISSN

0824-3298 (imprimé)

1927-8810 (numérique)

Découvrir la revue

Citer cet article

Arnold, R. (1990). 'Those Damn Sacred Hymns': Some Problems with the Ontology of 'Text'. Man and Nature / L'homme et la nature, 9, 57-67. https://doi.org/10.7202/1012610ar

Copyright (C Canadian Society for Eighteenth-Century Studies / Sociéte canadienne d'étude du dix-huitième siècle, 1990
Ce document est protégé par la loi sur le droit d'auteur. L'utilisation des services d'Érudit (y compris la reproduction) est assujettie à sa politique d'utilisation que vous pouvez consulter en ligne.

https://apropos.erudit.org/fr/usagers/politique-dutilisation/ 


\section{5. 'Those Damn Sacred Hymns': Some Problems with the Ontology of 'Text'}

In a letter to the Gentleman's Magazine of September 1794, an irate correspondent complains:

Two or three years ago I applied to Johnson, (a publisher) in St. Paul's Churchyard, for a couple of these little books of Divine Songs by Dr. Watts, which we have all learned by heart in our younger years. After I had brought them home, a friend, who remembered better than myself the studies of infancy, took them up, and observed, upon reading some of the Hymns, that they were not the same as they used to be. Some time after, we obtained another copy in the original dress, printed for Rivington, Longman, Dilly, \&c.; and, upon comparing them together, we found that Johnson's copy was completely travestied, every scrap of Trinitarianism, every intimation of the eternity of helltorments, \&c. carefully rooted out, and its place supplied by something, undoubtedly more liberal and more rational. (p. 805)

Textually, a congregational hymn does not appear to look any different from a poem as it is read on the page; ${ }^{1}$ therefore, the aspiring editor might reasonably assume that, fundamentally at least, conventional principles of poetic textual editing, with their usual problems, would apply. Considering that many hymns are so well known by so many people that they could probably be reproduced verbatim from memory, as the above writer recounts, and considering also that hymn-writers tend not to have left extant the kinds or numbers of drafts of their works that poets can plague the editor with, one is tempted to conclude that the hymn-editor might even get off easy. But as literary artifact the hymn possesses some peculiar properties quite apart from its prodigious musical complexities. The hymnal text indeed moves in mysterious ways, nor is it always the case with hymns that by their stanzas ye shall know them. While it is certainly true that the yoke of any editing job is neither easy nor its burden light, the editor of hymns is faced with questions and problems which, because of the remarkable uniqueness of the genre, lead him or her to question the applicability of some 
fundamental principles of textual establishment, and to seek an alternative strategy.

In some ways, the hymn is closer generically to the Anglo-Saxon or Classical tradition of oral poetry than to any modern literary conception of poetry. Like the oral narrative, which literally becomes the property of the successive tellers, the hymn in numerous cases becomes the property of subsequent compilers, ministers, ecclesiasts, or even other hymn-writers - their 'text' becomes the text; it serves its purpose among a certain community of users ${ }^{2}$ and is later revived and expectantly transfigured again. What matters most to oral narrators and hymn-writers is how the text functions, not what the text itself is; therefore, any changes made, no matter how substantive, require no acknowledgment on the part of the reviser. But while one can overlook the concern for an 'authoritative version' of a mythic narrative or heroic saga, and can accept for posterity that the resultant 'textual' chorus is the cumulative melding of a thousand tongues, the hymn, unlike the oral narrative, is first written (so technically there is a 'text') and is uttered anew by the thousand tongues later. Uniquely, the hymn's difference from both oral poetry and modern written poetry is that a 'popular' congregation holds, or hears recited, the text and is expected to sing or repeat (and, without involving too much contemplation or analysis, understand) the lines in unison, lines which are expected to serve a specifically designed spiritual and often sectarianistic purpose. ${ }^{3}$ In terms of their primary aim, hymns are created to be used, and under specific conditions by, initially at least, particular people, whereas poetry is created to be experienced, under any and all changing conditions, by a general and largely unspecified readership. But in terms of the phenomenology of artistic creation a distinction to observe is that while a poet might aim at creating a finished literary product - an aesthetic experience primarily 'for its own sake,' a hymn-writer might aim at initiating a literary process, the stem of a textual genealogy that should mature and attract a much larger gathering at some future time. So while an established or even 'definitive' text is sought after by the editor of the poem, - this presumably approaching most fully the author's 'intent' for that linguistic experience - in many cases it is instead a 'potential' text (or variety of texts) that the author may have 'intended' in the case of the hymn. (It is to be noted here that the term 'intent' is not used in its sense of being synonymous with projected interpretation or with what effect the author desires, but rather is used in the sense of 'intent' as an act or structure of articulated consciousness, or, how the author constitutes and presents his or her thoughts in a text).

This offering of a variety of possible texts or presentation of the source material for a genealogy of later texts is suggested by Isaac Watts in the 
Preface to his Hymns and Spiritual Songs (1707; enlarged in 1709). This volume - as Watts himself announces in his Preface - is essentially the first book of 'Hymns of meer Human Composure' to emerge in England: earlier hymn-books (as distinct from metrical Psalters) paraphrased scripture or based their hymns solidly upon specific scriptures which stood as headings for each hymn, whereas Watts, in a large portion of his volume, did not head up each hymn with a scripture citation, but rather indulged more freely his own imaginative interpretation or vision of Christian experience. In setting a controversial precedent ${ }^{4}$ and aiming itself specifically at congregational use, this book seems to have prepared itself for adjustments that might need to be made on the texts: Watts put many of his stanzas in square brackets ('crotchets' as he called them) and gave advance permission in his Preface for some or all of these to be left out if they are seen as either 'too poetical for meaner understandings,' 'too particular' for certain 'whole congregations to sing,' or just a trifle long-winded. In other words, if there are poetical objections, doctrinal and sectarian inconsistencies between the hymn and the congregation using it, or if it has to be fitted into a certain part of the worship service that does not allow sufficient time for the whole composition, a compiler may feel free to taketh the wheat and let chaff be still so that his congregation may indeed sing unto him a new song. One needs only to look at almost any popular Wattsian hymn in modern or even nineteenth-century hymnals and compare it to the original to see that what has come to be known as a certain hymn may have surprisingly little in common with its original. R. Palmer, Lord Selbourne, editing and compiling some Watts hymns in his volume of 1866, expresses the anguish of a troubled editorial heart when he examines the texts and observes: 'There is just enough of Watts left here to remind one of Horace's saying, that you may know the remains of a poet even when he is torn to pieces.'5

While textual editing in the eighteenth century in general is rather notorious for seeming to fall quite short of most modern ideals, compilers and editors of hymnals have traditionally taken textual liberties which editors of poetry would not (one hopes) see as their province. Stanzas are routinely deleted or reordered (e.g., dismembering whole hymns into centos without acknowledgement of the act has always been a routine practice). Titles are changed or discarded or invented afresh (e.g., often the first lines become titles: the title of 'Rock of Ages' is actually 'A Prayer, Living and Dying'; and 'When I Survey the Wondrous Cross' is actually 'Crucifixion to the World by the Cross of Christ'). Certain words, phrases, or lines are rewritten or 'amended' (e.g., Toplady's Calvinistic 'editing' of Wesley's Arminianism), or are put in italics or block type in order to emphasize certain doctrinal stances (e.g., Hart's 'Antinomianism' and Doctrine of Human Depravity). Whole 
sections or several stanzas of longer hymns, and even some shorter, are omitted: in fact it seems to have been a practice de rigeur among many hymn-writers to churn out many stanzas, sometimes 20 to 40 , for one hymn, knowing full well that while many are written, few are chosen only a handful of these stanzas would be selected out and born again to constitute 'the hymn' (e.g., Anne Steele, Christopher Smart, Charles Wesley, Thomas Olivers, and others). Certain theological flavours are drained only to be replenished with different ones (e.g. controversies concerning Arminianism vs. Election and Predestination, Doctrines of Sanctification and Perfectability vs Peccability and Divine Satisfaction, Trinitarian vs Arian and Unitarian stances, and issues of Pelagianism and Antinomianism, to name but a few, all find expression and profound revision in this the most widely read and memorized genre of the century). ${ }^{6}$ Favourite stanzas from several different hymns and writers are conflated to form a hymn under the name of yet another writer. And the 'editing,' though aiming to clarify, invariably neglects to give an account of the text or any credit to the 'real' author: it is expressive of sectarian biases, and contradictory from compiler to compiler. In addition, not only is plagiarism in no way reprehensible, but some hymnwriters have seemed quite naturally to trust in another writer with all their hearts and lean not to their own understandings (Simon Browne's use of Watts, and Philip Doddridge's use of Charles Wesley, are obvious examples); to borrow is human, to steal divine. The problem, ultimately, is that many hymns - particularly, it seems, the better-known Sunday best - exist in several very different forms: in fact, some of these are virtually unrecognizable in their original form. To verify their textual 'authenticity' is rarely a clear matter of black and white, but is rather a babble of amazing grays.

In view of these complexities, one might be tempted to opt for the first extant version or first published text - since this, in many cases, is what was used; and use, rather than any desire for pristine immortality, seems to have been the writer's main aim for their texts, But what confounds this strategy is knowledge of the fact that in many cases the open possibility of later textual changes - even by others - carries the blessing and approval (sometimes in advance, sometimes afterwards, sometimes unknown) of the original author; so a later version might (and often does) more fully capture the author's 'intention' for that hymn. The most notorious and complex example is Charles Wesley's virtual editorial blank cheque given to his brother John, who, when presenting Charles's best-known hymns in the famous 1780 volume, happily devoted himself to all the editorial gymnastics outlined above, and gave no account whatsoever of his intervention. ${ }^{7}$ Therefore, and on the other hand, final intent becomes a primary concern: if any text be 
substantially revised it is a new creature, the old is passed away, the work becomes new. But this strategy (or any strategy that aims at establishing one text, or even a preferred text) implies that at some point there is a point where, in the author's mind, an immaculate conception of the text takes place, even after 40 years of wilful wandering in the wilderness of variants. Underlying most editorial strategies, traditional and recent, is the concept of authorial intent, this in turn providing the rationale for the principle of the ontological status of 'copy-text'. But the importance of establishing a 'copy-text' or any sort of authoritative version seems in many cases not to have been an issue of much importance; and since some hymn-writers, unlike poets, seem to have gladly watched their hymns continually reappear in Protean unpredictability, the question of authorial intent and the definitive status of the 'text' become problematic indeed. The traditional editorial concept of the text as an established aesthetic object (albeit with variants) or a relatively fixed ontology seems less efficacious and relevant here (with hymns) than a conception of the text as a phenomenological matrix that provides the conditions for the functionality, and possibilities for the variability, of itself as a dynamic textual and contextual process.

To illustrate. One of the most popular hymns that has had (and still has) extensive use in most English-speaking countries, and that has been translated into many languages, and that even occasional churchgoers have at least heard of, or sung, at some point, is 'Lo! He comes with clouds descending'. In terms of fame and usage, this hymn is nearly unsurpassed, so there is no question but that it should be included in any anthology of hymns: it contains all the finest ingredients of a great hymn, and is a premier example of the genre in action.

But which text to use? By the end of the nineteenth century there were at least 20 versions of the hymn, these ranging from the replacement of a few words, to the rewriting of several lines, to very major changes. This is to be expected, however, in such a popular hymn, and it therefore seems a reasonable strategy for the editor to go to the 'original' text, the genealogical base from which the subsequent revisions were made. This leads to Martin Madan's Collection of Psalms and Hymns (1760), Hymn No.42 in 6 stanzas of 6 lines each. But this is an odd finding since the hymn is traditionally associated with Charles Wesley and has appeared under his name in some subsequent hymnals, and because Madan is certainly not known for his hymn-writing, much less for stanzas with this kind of power. Indeed, in Wesley's Hymns of Intercession for All Mankind (1758) the hymn appears as No.39, but in 4 stanzas of 6 lines each. And one of Madan's stanzas (stanza 5) is not from Wesley's version, only 3 of the 6 are. Wesley, then, would appear to be the author (of at least half the hymn) and Madan a major reviser, or substantial 
supplementer, upon whose version a major genealogy of later texts would be based. However, although Madan was unquestionably an industrious collector and recaster of hymns, there is no evidence that he ever wrote a hymn of his own, or even stanzas of his own (especially stanzas this popular). Where did his additional 3 stanzas (stanzas 3, 4 and 5 - virtually half the hymn) come from? It turns out - and this is by no means unusual - that 2 of these stanzas (and the crucial closing line of Madan's hymn) are actually stanzas 3 and 5 (and closing line) of a hymn by another writer, John Cennick, entitled 'Lo! He cometh, countless trumpets' (6 stanzas of 6 lines each) in his Collection of Sacred Hymns of 1752. As for Madan's fifth stanza, it is from another Wesley hymn, No.38, entitled, 'Rise, ye dearly purchased sinners' of the 1758 volume.

In short, it is rather hazardous to see the 1760 text as the original or stem of 'Lo! He comes with clouds descending', when in fact it is textually constituted as follows: stanzas 1 and 2 (with one line changed) are from Charles Wesley (1758); stanzas 3 and 4 (with two lines and two phrases changed) are from John Cennick (1752); stanza 5 (with a word change) is from Wesley (but from a different hymn in the 1758 volume); and in stanza 6 the first 3 lines are from Wesley and the closing line from Cennick. Only the cut-and-paste arrangement is Madan's. Furthermore, subsequent versions invariably omit stanza 5 and alter quite unabashedly lines and phrases of the Madan text. To complicate matters further, Thomas Olivers, who apparently wrote the original tune for the hymn, composed a 20-stanza version of the hymn (no date, but later 36 stanzas in 1763), called it 'Come, immortal king of glory,' and used several lines from the hybrid Madan text. Portions of this version became quite famous, and in later versions (Selbourne, 1862 and Thring, 1882) compilers tended to use these as well as the earlier texts, while feeling quite free to revise further this textual montage. The 'text' of 'Lo! He comes with clouds descending' passed through the hands of compilers, writers, and editors, each of whom had his own contextual considerations out of which the text of the hymn was revived and dressed anew: different theological beliefs, doctrinal alignments, congregational and perhaps personal preferences subjected this valued and resilient hymn to a textual process which seems to defy any traditional editorial aim of establishing one text as the text, or even as a basic text.

Such a process was not unusual, and seems to have been generally expected in many cases, not only by editors and compilers but by the hymn-writers themselves. To give some attention to this process might help to explain why, among other things, hymnal stanzas seem for the most part to be quite self-contained: there is rarely a coherent progression or development, a fluent linkage of stanzas, and even though many 
hymns present a narrative or story from powerful and memorable Biblical episodes, there is rarely narrative development, continuity and consistency of voice (let alone a sense of drama), nor is there a sense of the organic unity or progressive narrative power that would make these poem-like structures more like good poems: many hymns read more like a collection of stanzas - though individually quite powerful stanzas than a unified artistic entity. Accordingly, these poetic shortcomings of hymns may have perpetuated the age-old dismissal of hymns from serious literary study because they are lousy poems. (Significantly, these 'problems' don't seem to exist in eighteenth-century songs: the narratives and stories in popular songs often develop quite compellingly and are suspenseful and dramatic; they encourage the reader to make partial closures toward the climactic outcome and resolution). ${ }^{8}$

This textual-contextual process might also explain another peculiarity which is inescapable to the editor of hymns, and even to the book collector or anyone interested in first editions of hymn-books: if the hymns were meant to be used by congregations, why are so many hymns - particularly in their 'original' form - so long? Why so many stanzas? Even in volumes which have hymns 'designed specifically for' such-and-such occasions, fasts, festivals, spiritual states, etc., it is curious how a hymn of, say, 30 quatrains could be expected to be used at a particular point in the service or meeting. Hymn-writers probably knew, even early in the century, that if their hymns were to be selected for collections and/or used by congregations they would need to conform roughly to the 8 or 9 stanza maximum length that seemed to be (if one looks at virtually any widely used compilation) the unofficial cut-off point for compilation and for use, with 4 to 6 stanzas being optimum. ${ }^{9}$ Add to this that if the hymn were to be uttered to a plain-song format, or if it were to be lined-out ${ }^{10}$ piecemeal and repeated, as were psalms, considerable time would be required to get through a hymn of just moderate length. Even if it were to be sung to a popular tune at an outdoor meeting (as were many Methodist and Evangelical hymns) the preference seems to have been for short, manageable, and memorizable hymns that would stir up a gathering and prepare the way for the 'message. ${ }^{11}$

Anne Steele's well-known hymn entitled: 'Come, heavenly love, inspire my song', is a case in point. Steele, whose hymns achieved astounding popularity and usage for more than a century after their appearance in 1760 (only Watts, Wesley, Doddridge and Cowper were more frequently compiled), published 39 quatrains in the original version of this widely compiled hymn. Two of the most popular contemporary hymnals of the time, however, (Ash and Evans's Collection of 1769 and Conyers's Collection of 1772), select 7 stanzas (1,2,3,7,8,37, and 39), 
and these, with no footnote of explanation, as usual, or any account whatsoever of editorial intervention, stand as the hymn. Subsequent major collections (Uttoxeter of 1805 and Cotterill of 1810, and the several later editions of Cotterill's immensely popular book) shorten it to 6 stanzas (1,2,3,7,8, and an unidentified final stanza) and, in a significant and topical shift in doctrinal stance, change the title from 'Come, heavenly love, inspire my song' to 'Come, Holy Ghost, inspire our songs. ${ }^{12}$ In this form it passed into several English collections; but its first major appearance in America (Hall and Lasar of 1880) saw the inclusion of 8 stanzas (1,2,3,8,32,33,37 and 39), and the title amended to 'Come, heavenly Dove, inspire my song.' Steele, very much a confessed admirer of Watts, did not need to follow his lead in putting the optional brackets around some of her stanzas, probably because the tentativeness of hymnal texts was well known and accepted by this time.

Even a cursory look at this particular hymn (the same is true of many others) suggests that some of the stanzas seem to hold a deliberately tentative and even dispensable position in the composition. First of all, some of the stanzas seem repetitive as they approach a given topic (God's mystery, Christ's suffering, man's vileness, God's triumph) from different vantage points or with a slightly different focus, as though the reader may select a preferred treatment - or combination of treatments - of the respective topics. Second, while part of the hymn is a narrative of the crucifixion and resurrection, one can just read alternate stanzas (even or odd) and still obtain a workable and satisfying set of images of these events; the whole thing seems conspicuously redundant. Third, even though these events could easily provide a writer with rather gripping and intense narrative material, each stanza seems so self contained (or even to be a new departure) that there is very little in the way of denouement or climax; there does not seem to be any one far off event toward which the whole stanzaic creation dramatically moves. Finally, the grand ascent of Christ on high, while claiming 6 or 7 stanzas, seems clearly and in fact powerfully conveyed by each or any of these stanzas.

Significantly, these kinds of peculiarities, which may undoubtedly be seen as poetic flaws of considerable magnitude, seem not to occur in Steele's poetry - as opposed to her hymnody (one volume of her 3-volume work is specifically called poetry, a second is prose, and a third is hymns). Some of Steele's poetry - even on 'divine subjects' - does seem to possess the narrative power, stanzaic continuity, and organic unity conspicuously lacking in the hymns. In fact, if one considers other writers who produced hymnody and poetry (e.g., Watts, Cowper, Smart), similar comparisons become evident: the hymns differ in significant ways other than just by subject matter. It may seem curious indeed, to those literary critics who tend to pass over hymns with a circumspect 
deferential tolerance, that the authors of such reputable works as Horae Lyricae, The Task, and A Song to David also penned literary creations which seem noticeably inconsistent, in terms of the poetic qualities outlined here, with their poetry. Steele is, admittedly, no recognized poet; but while it seems obvious to say that her poems are better poems than are her hymns, this could be because when writing hymns she is knowingly engaged in a genre which has unique phenomenological, structural, and ultimately ontological properties governing its mode of creation, properties very different from those governing the composition of a poem. Put simply, the aim seems to be to make a sufficient number of individual stanzas powerful, sharp, and unified so that something can be used from the collection of stanzas. Of decidedly secondary importance is the need to knit all these stanzas naturally and coherently into the larger fabric of the whole hymn.

In what seems like an inversion of traditional standards of poetic propriety, it often does seem to be the case with hymns that the parts are of greater importance than the whole, and need not even add up to a whole - and the writers may, during some of their more inspired hymnal (as distinct from poetic) moments - have had this in mind during composition. As with writers, so with editors as well. To edit hymns by established procedures and assumptions appropriate to other literary texts, and therefore to seek the one version that may be reasonably safely said to provide the ontological status of the copy-text (or full and final intent), may be proper in some cases - maybe even in many cases. But in many other cases this not only involves an editorial impasse, but, more important, it acts as a thief in the night, robbing the hymnal text of its most significant and unique quality: its Protean and Pauline ability to continually put on different garments of praise and, not unlike Lazarus, to be transformed and revived in order to remain such a pervasive and animated part of popular consciousness. In these cases any edition needs to present the dominant sources (often plural) of the textual genealogy and to explain through annotation the different contexts through which the hymn has passed. It is necessary to clarify the otherwise perplexing fact that the version of the hymn which came to be known as that hymn is sometimes the result of an accumulation of contexts which transformed the text of the hymn in order that its main goal and final intention - popular usage, not literary significance or beauty - could be, and was, sustained. Thus keeping the dynamic and melodious faith of our fathers living still.

RICHARD ARNOLD

University of Lethbridge 


\section{Notes}

1 While in modern hymnals the hymns often tend to appear with the musical scores, most earlier hymn volumes, particularly those of the eighteenth century, print only the verbal texts; the various tunes were applied to specific hymns (and just as quickly changed) subsequent to the publication of the hymn volume. Tunes from different sources were sometimes collected into volumes of their own: two examples are Harmonia Sacra, or, A Choice Collection of Psalm and Hymn Tunes in Three Parts for the Voice, Harpsicord, and Organ (London, n.d. [circa 1720]) and Robert Bremner's The Rudiments of Music: or, a Short and Easy Treatise on that Subject. To Which is Annexed, A Collection of the Best Church Tunes, Canons, and Anthems (Edinburgh, 1762). For an account of hymn tunes see Robert McCutchan, Hymn Tune Names (New York, 1977), and David W. Perry, Hymns and Tunes Indexed (London, 1980).

2 Titles of some famous hymn-books reveal that many hymns in the eighteenth century were written and/or collected with a specific congregation in mind (e.g., the Olney Hymns by Cowper and Newton (1779); Walworth Hymns by Joseph Swain (1792); A Collection of Hymns for the Use of the People Called Methodists by John and Charles Wesley (1780); The Collection of Hymns Sung in the Countess of Huntingdon's Chapels (1774); A New Edition of Select Psalms and Hymns, for the Use of the Parish Church and Chapels Belonging to the Parish of St. James, Westminster (1795), etc). Even Isaac Watts, whose hymns have been in use by widely varying denominations for nearly three centuries, wrote his earliest hymns specifically for the Independent Meeting House he attended with his father in Southampton in 1694, and his later hymns for Mark Lane Chapel where he was pastor from 1702 onwards.

3 Though beyond the scope of the present discussion, it is useful and interesting to trace the theological and doctrinal revisions made by 'editors' of hymns for their congregations.

4 Hymns were a controversial phenomenon in the late seventeenth and early eighteenth centuries, and the issue of to sing or not to sing found expression in persisterit debate and vociferous pamphleteering. England had followed Calvin rather than Luther on this Reformational issue, thus restricting corporate singing to metrical Psalms and scriptural paraphrases. This 'Controversie of Singing' found voices in many religious sects: the Church of England and the Roman Catholic Church did not allow hymns; General Baptists opposed hymns while Particular Baptists sang them occasionally; Independents tolerated them while the Society of Friends would not sing them congregationally; Methodists and certain Evangelicals were to encourage hymns, but only those written by their own leaders. Given this tense situation, in 1707 Watts harboured serious doubts about whether or not to publish his 'Hymns of meer Human Composure'; only after considerable importuning from his brother Enoch and other dissenting friends of the Independent sect did he consent to send his work to the press.

5 English Church Hymnody (York, 1866), Preface.

6 Nicholas Temperley, in The Music of the English Parish Church (Cambridge, 1979), summarizes the power of congregational singing: 'One of the strongest weapons in the hands of the reformers was popular song. Religious polemics, theological reasoning, and attacks on superstition could make little appeal to the ordinary people, but they could and did respond warmly to the opportunity to take part in the music of worship' (p. 19). 
7 Though several of John's revisions of Charles's hymns seem to be quite substantial, there seems to have been no need for John even to acknowledge his intervention: this general practice was not unusual, and Charles seems to have accepted the changes for editions subsequent to 1780. In The Hymns of Methodism in Their Literary Relations (London, 1913), Henry S. Bett claims that John and Charles agreed that they would not distinguish between each other's work, and that agreement was kept until Charles married and it became necessary to identify his literary property (p. 21).

8 See $A$ Select Collection of English Songs, in Three Volumes (London, 1783). It is interesting, in addition, that many of these songs are set in the same measures as are many hymns.

9 Not only are most compilations filled with hymns of remarkably uniform length, but equally noteworthy are eighteenth-century hymnal contributions to magazines. Often in the 'Poetical Essays' sections of The Gentleman's Magazine, The London Magazine, The Lady's Magazine, etc. (1740-1800) hymns are printed that various writers have sent in, usually, though not always, for particular occasions. In most cases the length of these hymns is a repetitively uniform 5-10 stanzas.

10 As was the case with Psalms, the parish clerk, often a trained musician, would read out a line or pair of lines from the hymn, and would then lead the congregation in singing them. (For an illustration of this practice see the section in Richardson's Pamela which describes the service in Mr. B.'s chapel the Sunday before his wedding). Since singing was usually a small part of most worship services, and since this process would take considerable time, one can see why the 4 to 6 stanza length would probably not only be preferred but probably necessary in order for the hymn to be used at all.

11 In Minutes of the Methodist Conferences (1744-1798) John Wesley advises, 'Do not suffer the people to sing too slow, avoid repetition, and sing quickly and with energy' (1768, p. 80, McMaster Special Collections). He also advises 'all the Preachers' 'Always to conclude the service in about an hour' (1786, p. 192). It would seem that shorter hymns would surely be required in the case of these outdoor and less traditional worship services as well.

12 A slightly more conspicuous tinge of Trinitarian Arminianism seems to be suggested in this title change. 